\title{
STUDI KANDUNGAN FLUORIDA PADA AIR PENAMPUNGAN AIR HUJAN
}

\author{
Ayu Novinda Nurul Putri' ${ }^{1)}$, Sugeng Abdullah²) \\ Poltekkes Kemenkes Semarang, Poltekkes Kemenkes Semarang
}

\begin{abstract}
Abstrak
Fluorida $(\mathrm{F})$ dalam jumlah kecil $(0,5 \mathrm{mg} / \mathrm{L}$ air $)$ dibutuhkan sebagai pencegahan terhadap penyakit karies gigi yang paling efektif. Umumnya, air hujan tidak mengandung fluorida. Penelitian ini bertujuan untuk mengetahui bahan bidang penangkap air hujan, unit pengolah air hujan, bahan bak penampung air hujan, kandungan fluorida air di penampungan air hujan, suhu, $\mathrm{pH}$ dan kekeruhan. Jenis penelitian termasuk penelitian deskriptif dengan cara observasi dan wawancara, pemeriksaan kualitas air dan dokumentasi. Hasil penelitian menunjukkan bahan bidang penangkap air hujan adalah seng galvalum, unit pengolah air hujan adalah saringan kain, bahan bak penampung air hujan adalah ferrosemen berlapis plastik polyethylene, jerican dan drum HDPE, dan tangki air polyethylene. Kandungan fluorida air hujan $0,0002 \mathrm{mg} / \mathrm{l}-0,0004 \mathrm{mg} / \mathrm{l}$. Parameter suhu $20^{\circ} \mathrm{C}-21^{\circ} \mathrm{C}$, pH 8,1 - 8,4 dan kekeruhan <5 NTU, sudah memenuhi syarat kesehatan. Kuantitas air sudah memenuhi standar kebutuhan air bersih. Kesimpulan penelitian ini adalah komponen penampungan dan proses pengolahan air hujan belum memenuhi syarat. Kualitas fisik air ( $\mathrm{pH}$, suhu, kekeruhan) memenuhi syarat, terdapat kandungan fluorida yang diduga berasal dari migrasi bahan bak penampungan. Saran penulis adalah perlu dilakukan proses fluoridasi dan penelitian lebih lanjut mengenai migrasi senyawa fluorida dari bahan bak penampungan air hujan.
\end{abstract}

Kata kunci: Penampungan air hujan; fluorida

\begin{abstract}
Fluoride $(F)$ in trace amount $(0,5 \mathrm{mg} / \mathrm{L})$ is needed as the most effective way to prevent dental caries. Generally, rainwater does not contain fluoride. This research aims to know catchment material, water treatment unit, storage material, fluoride level in rainwater, temperature, $\mathrm{pH}$ and turbidity. The research method used is descriptive by collection by observation and interview, water quality inspection and documentation. The result were obtained as follows: catchment material used is galvalume metal sheet, water treatment unit used is filter from cloth, storage tank material is polyethylene coated ferrocement, HDPE jerrycans dan drum, dan polyethylene tank. Fluoride level in rainwater are from 0,0002 $\mathrm{mg} / \mathrm{l}-0,0004 \mathrm{mg} / \mathrm{l}$. Water temperatur is $20^{\circ} \mathrm{C}-21^{\circ} \mathrm{C}, \mathrm{pH} 8,1-8,4$ dan turbidity $<5 \mathrm{NTU}$, these parameters already fulfill the health provision. Water quantity already fulfill the water needs standard. The conclusion is rainwater harvester component and water treatment process does not fulfill the requirement. Water physical quality ( $\mathrm{pH}$, temperatur, turbidity) already fulfill the requirement. Fluoride contents in rainwater suspected from storage material migration. The recommendation is water fluoridation and advanced research about migration of fluoride compound from storage material is needed.
\end{abstract}

Keywords: Rainwater Harvester; Fluoride

\footnotetext{
${ }^{1)}$ E-mail: ayunvd@gmail.com

${ }^{2)}$ E-mail: sugengzend@gmail.com
} 


\section{Pendahuluan}

Air merupakan salah satu kebutuhan pokok hidup manusia dan makhluk hidup lainnya, bahkan dalam tubuh manusia hampir $70 \%$ berat badan terdiri dari air. Organisasi Kesehatan Dunia (WHO) menetapkan kebutuhan air per orang per hari untuk hidup sehat adalah 60 liter untuk daerah pedesaan dan 150 liter untuk daerah perkotaan.

Menurut Water Aid pada 2016 (Perpamsi, 2018), Indonesia masuk daftar negara dengan penduduk terbanyak yang tidak bisa mengakses air bersih. Indonesia berada di peringkat ke-6 dari 10 negara. Ada sekitar 32 juta orang di Tanah Air hidup tanpa air bersih. Adapun Badan Pusat Statistik (BPS) mencatat bahwa sampai tahun 2016, capaian akses air minum baru mencapai 71,14 persen dan akses sanitasi 76,37 persen. Kontribusi air minum perpipaan sendiri diperkirakan baru mencapai 26 persen.

Berdasarkan data sementara yang dihimpun Pusat Pengendali Operasii (Pusdalops) Badan Nasional Penanggulangan Bencana (BNPB), Setidaknya, terdapat sekitar 105 kabupaten/kota, 715 kecamatan, dan 2.726 kelurahan/desa yang mengalami kekeringan di Jawa dan Nusa Tenggara. Salah satu daerah yang kesulitan mendapatkan air bersih di Pulau Jawa adalah Dusun Bambangan, Desa Kutabawa, Kecamatan Karangreja, Kabupaten Purbalingga, Jawa Tengah.

Dusun Bambangan merupakan dusun terakhir yang terletak di kaki Gunung Slamet pada ketinggian 1.502 mdpl dan merupakan basecamp pendakian Gunung Slamet. Terletak di daerah yang tinggi menyebabkan akses ke sumber air sulit dijangkau. Selain itu, letaknya yang terlalu tinggi dan kemiringan yang terlalu curam menyebabkan proyek penyediaan air bersih seperti PAMSIMAS tidak dapat terealisasi.

Untuk mengatasi masalah tersebut, warga Dusun Bambangan memanfaatkan air hujan dengan membuat penampungan air hujan di rumah masingmasing. Air hujan dimanfaatkan untuk mandi, memasak, air minum dan mencuci tanpa ada pengolahan terlebih dahulu. Selain itu, sampai saat ini belum dilakukan pemeriksaan oleh instansi yang berwenang terhadap kualitas air di penampungan air hujan warga Dusun Bambangan. Hal ini dapat berdampak buruk bagi kesehatan karena dilihat dari proses pembentukannya, air hujan merupakan air yang miskin mineral, salah satunya mineral fluorida. Berdasarkan penelitian yang telah dilakukan, kandungan mineral fluorida air hujan khususnya di Kota Malang, Jawa Timur hanya 0.4 ppm (Untari, dkk. 2015 h. 1497).
Air minum yang dikonsumsi oleh masyarakat, harus memenuhi persyaratan kualitas dan kuantitas. Parameter kualitas air yang ditetapkan terdiri dari parameter fisik, bakteriologi, radioaktif dan kimiawi. Beberapa parameter kimiawi diduga berpengaruh terhadap kesehatan gigi, antara lain unsur fluorida, kalium, kalsium, dan keasaman $(\mathrm{pH})$ air.

Fluorida (F) dalam jumlah kecil $(0,5 \mathrm{mg} / \mathrm{L}$ air $)$ dibutuhkan sebagai pencegahan terhadap penyakit karies gigi yang paling efektif tanpa merusak kesehatan (Sutrisno, 2010). Konsentrasi fluorida dalam air berhubungan erat dengan jenis sumber air. Pada umumnya konsentrasi fluorida di air tanah dan air permukaan melebihi syarat diatas. Sebaliknya pada jenis sumber air bersih lain seperti air hujan kandungan fluor dalam air sangat sedikit dan dapat menyebabkan karies gigi sehingga perlu dilakukan fluoridasi air.

Karies gigi adalah sebuah penyakit infeksi yang merusak struktur gigi (MedlinePlus Medical Encyclopedia, 2006). Penyakit ini menyebabkan gigi berlubang. Di Indonesia, menurut hasil Riset Kesehatan Dasar 2007 (Jennifer, 2015 h.118), prevalensi karies gigi aktif penduduk usia 12 tahun ke atas sebesar $43,4 \%$ dan pengalaman karies sebesar $67,2 \%$ dengan rerata tingkat kerusakan gigi sebesar 4,85\% (Departemen Kesehatan, 2008). Artinya rerata penduduk Indonesia usia 12 tahun keatas telah mengalami kerusakan gigi sebesar 5 buah per orang. Karies gigi yang merupakan masalah utama penyakit gigi dan mulut, bila tidak dilakukan pencegahan dan perawatan maka akan semakin parah dan meningkat kasusnya.

Berdasarkan permasalahan tersebut, peneliti tertarik untuk melakukan penelitian yang berjudul "Studi Kandungan Fluorida pada Air Penampungan Air Hujan di Dusun Bambangan, Desa Kutabawa, Kecamatan Karangreja, Kabupaten Purbalingga Tahun 2018”.

\section{Bahan dan Metode}

Penelitian ini termasuk jenis penelitian deskriptif dengan cara melakukan observasi dan wawancara mengenai penampungan air hujan, dokumentasi, serta pemeriksaan kualitas air meliputi suhu, $\mathrm{pH}$, kekeruhan dan fluorida.

Waktu dalam penelitian ini dibagi menjadi 3 tahap yang pertama tahap persiapan SeptemberJanuari 2017, tahap pelaksanaan Januari-April 2018, dan tahap penyelesaian Mei 2018.Cara Pengumpulan Data yaitu dokumentasi dilakukan untuk mendapatkan data profil Desa Kutabawa dan jumlah penampungan air hujan di Dusun Bambangan, kemudian observasi dilakukan untuk memperoleh data bahan bidang penangkap air, bahan bak penampungan air hujan dan 
unit pengolahan air hujan lalu yang terakhir yaitu pemeriksaan laboratorium dilakukan untuk memperoleh data kandungan fluorida, suhu, $\mathrm{pH}$ dan kekeruhan.

Instrumen pengumpul data dalam penelitian ini berupa dokumen dari Kantor Desa Kutabawa, ceklist penampungan air hujan, ceklist kondisi umum kesehatan lingkungan dan seperangkat alat laboratorium.

Analisis yang digunakan dalam penelitian adalah deskriptif dengan menguraikan hasil yang disajikan dalam bentuk tabel, grafik dan narasi. Kemudian data dibandingkan dengan acuan teoritis serta standar persyaratan yang berlaku.

\section{Hasil dan Pembahasan}

\section{A. Gambaran Umum}

Keadaan Geografi : Dusun Bambangan merupakan salah satu dusun di Desa Kutabawa, Kecamatan Karangreja, Kabupaten Purbalingga. Dusun ini berada pada ketinggian 1.502 mdpl. Bambangan terdiri dari $1 \mathrm{RW}$ yang dibagi menjadi 3 RT yaitu RT 17 RW 05, RT 18 RW 05 dan RT 19 RW 05. Penduduk Dusun Bambangan berjumlah 1.312 jiwa dengan jumlah KK 379. Di Dusun Bambangan terdapat 234 unit rumah. Mayoritas penduduk Dusun Bambangan bekerja sebagai petani sayur-sayuran.

Dusun Bambangan merupakan salah satu jalur pendakian Gunung Slamet. Dusun ini merupakan dusun terakhir menuju jalur pendakian. Berada di ketinggian 1.502 mdpl, Dusun Bambangan termasuk dusun yang sulit mendapatkan air bersih. Hal ini disebabkan karena di Dusun Bambangan tidak ditemukan mata air dan sulitnya membuat sumur bor. Aliran air tanah yang terlalu dalam dan struktur tanah yang berbatu membuat warga tidak mampu membuat sumur bor.

Menurut Henry (1998 h. 456), tanah di daerah dengan gunung-gunung memiliki kemiringan yang curam. Sama halnya dengan Dusun Bambangan, letaknya yang terlalu tinggi, kemiringan yang curam dan tidak terdapat mata air menyebabkan proyek penyediaan air bersih seperti PAMSIMAS tidak dapat terealisasi di Dusun Bambangan. Untuk mengatasi hal ini, warga menggunakan air hujan sebagai alternatif terakhir untuk mencukupi kebutuhan air bersih mereka.

Kondisi Umum Kesehatan Lingkungan : Dusun Bambangan merupakan Dusun dengan lingkungan yang sejuk dan asri. Penduduk Dusun Bambangan memiliki rumah dengan bangunan permanen dan semi permanen. Lahan di sekitar rumah penduduk dimanfaatkan sebagai lahan pertanian dan kandang ternak. Lingkungan Dusun Bambangan bersih dengan tidak terlihat sampah yang berserakan.

Di Dusun Bambangan tidak ditemukan mata air, selain itu proyek penyediaan air bersih seperti PAMSIMAS tidak terealisasi di dusun ini. Alternatif terakhir, sumber air bersih yang digunakan penduduk
Dusun Bambangan berasal dari air hujan. Curah hujan yang tinggi sepanjang tahun dapat mencukupi kebutuhan air penduduk. Ketika kemarau tiba, penduduk harus membeli air dari mobil tangki air yang datang tetapi hal ini sangat jarang terjadi. Penggunaan air hujan ini cukup sederhana. Penduduk menampung air hujan yang jatuh dari atap rumah di sebuah bak penampungan.

Menurut BPPT, rain harvesting atau pemanenan air hujan adalah kegiatan menampung air hujan secara lokal dan menyimpannya melalui berbagai teknologi, untuk penggunaan masa depan untuk memenuhi tuntutan konsumsi manusia atau kegiatan manusia. Di Indonesia, penggunaan penampungan air hujan banyak digunakan di daerah dengan ketersediaan air tawar yang terbatas.

Sebuah sistem pemanenan air hujan terdiri dari tiga elemen dasar yaitu area koleksi, sistem alat angkut dan fasilitas penyimpanan. Di Dusun Bambangan, elemen penampungan air hujan yang digunakan yaitu area koleksi (atap rumah) yang berbahan seng galvalum, sistem alat angkut (talang air) yang berbahan PVC dan fasilitas penyimpanan (bak penampungan air hujan) yang terdiri dari bak ferrosemen, jerican, drum dan tangki air. Mayoritas penduduk Dusun Bambangan belum memiliki sistem penampungan air hujan yang sesuai dengan referensi. Masih banyak penampungan air hujan yang hanya terdiri dari dua elemen yaitu area penangkap air hujan dan bak penampung air hujan.

Selain itu menurut UNEP (2001), penyaringan perlu dilakukan untuk mencegah masuknya kontaminan ke dalam bak penampungan. Sumber utama dari kontaminasi adalah kontaminasi dari bahan bangunan, burung, kotoran hewan dan serangga yang masuk kedalam bak penampungan. Bak penampungan yang terbuka tidak direkomendasikan untuk menyimpan air yang akan dimanfaatkan sebagai air minum. Sebuah tutup yang aman diperlukan untuk mencegah perkembangbiakan nyamuk, mencegah masuknya serangga dan hewan lainnya kedalam bak penampungan dan untuk menghindari masuknya sinar matahari kedalam bak untuk mencegah tumbuhnya alga. Di Dusun Bambangan, mayoritas sistem penampungan air hujan yang digunakan tidak dilengkapi dengan saringan dan dalam kondisi yang selalu terbuka. Hal ini berakibat pada terdapatnya berbagai partikel kotoran pada air di dalam bak penampungan.

Penduduk Dusun Bambangan mengalirkan limbah cair domestiknya ke selokan yang nantinya akan diresapkan. Sedangkan untuk tinja, penduduk Dusun Bambangan sudah menggunakan septic tank. 
ISSDP (2010 h.18) menyatakan bahwa sistem pengolahan air limbah dibagi menjadi tiga yaitu sistem setempat dimana air limbah langsung diolah di tempat, sistem terpusat dimana air limbah dialirkan melalui perpipaan ke IPAL, dan sistem hibrida yaitu kombinasi dari sistem terpusat dan sistem setempat. Menurut ISSDP, sistem setempat yang memadai perlu ceruk atau tangki untuk menampung endapan tinja (sludge), juga tergantung pda permeabilitas tanah untuk menapis air limbah ke dalam tanah. Dengan demikian, pengolahan limbah di Dusun Bambangan sudah cukup baik.

Di Dusun Bambangan belum tersedia fasilitas untuk pengumpulan dan pengangkutan sampah. Penduduk mengelola sampahnya sendiri-sendiri. Pendudduk mengolah sampah dengan cara membakar sampah plastik dan mengubur sampah organik di kebun. Kotoran ternak dimanfaatkan sebagai pupuk. Penduduk tidak melakukan daur ulang sampah.

Menurut PP No 81 Tahun 2012 Tentang Pengelolaan Sampah Rumah Tangga dan Sampah Sejenis Rumah Tangga, setiap orang wajib melakukan pengurangan sampah dan penanganan sampah. Pengurangan sampah dilakukan dengan pembatasan timbulan sampah, pendauran ulang sampah dan pemanfaatan kembali sampah. Penanganan sampah meliputi pemilahan, pengumpulan, pengangkutan, pengolahan dan pemrosesan akhir sampah. Pemrosesan sampah meliputi proses pemadatan, pengomposan, daur ulang mater, dan/atau daur ulang energi. Pengelolaan sampah di Dusun Bambangan belum sesuai dengan PP No 81 Tahun 2012 Tentang Pengelolaan Sampah Rumah Tangga dan Sampah Sejenis Rumah Tangga. Meskipun demikian, Dusun Bambangan tetap terlihat bersih dan tidak ada sampah yang berserakan.

\section{B. Data Khusus}

\section{Penampungan Air Hujan}

Menurut Abdulla et al., (2009); Song et al., (2009); UNEP (2001) (Yulistyorini, 2011 h.107), Sistem PAH umumnya terdiri dari beberapa sistem yaitu: tempat menangkap hujan (collection area), saluran air hujan yang mengalirkan air hujan dari tempat menangkap hujan ke tangki penyimpanan (conveyance), filter, reservoir (storage tank), saluran pembuangan, dan pompa. Di Dusun Bambangan, Komponen penampungan air hujan di setiap rumah bervariasi. Komponen Penampungan Air Hujan yang umumnya terdiri dari bidang penangkap air hujan, bak penampungan air hujan dan unit pengolahan air hujan.

Bidang Penangkap Air Hujan : Bidang penangkap air hujan berupa atap rumah yang berbahan seng galvalum. Thomas dan Martinson (2007, h.60) menyatakan bahwa atap dengan jenis seng memiliki koefisien run off $>0,9$ sehingga air hujan dapat mengalir dengan baik ke bak penampung. Kualitas air hujan yang melewati atap seng sangat baik. Permukaan seng yang halus dan memiliki suhu tinggi membantu mensterilkan bakteri. Namun, penggunaan seng sebagai bidang penangkap dapat merugikan apabila seng yang digunakan sudah berkarat. Seng yang berkarat dapat menyababkan air yang tertampung terkontaminasi oleh partikel hasil korosi .Bahaya yang ditimbulkan dari korosi adalah akan merusak jaringan dalam tubuh manusia (Wahyu et al, 2014 h.355).

Setelah melewati atap rumah, air hujan akan mengalir menuju bak penampungan air melalui talang air atau langsung ke dalam bak. Berdasarkan penggunaan talang air, terdapat dua sistem penampungan air hujan yaitu penampungan air hujan dengan talang air dan penampungan air hujan tanpa talang air. Talang air yang digunakan berjenis PVC. Menurut UNEP (2001), jenis pipa atau talang yang digunakan sebagai pengalir air hujan sebaiknya terbuat dari material plastik, PVC, atau zat inert lainnya untuk mengantisipasi $\mathrm{pH}$ air hujan yang dapat bersifat asam dan menyebabkan korosi dan migrasi zat kimia pada pipa logam. Dengan demikian, penggunaan talang air berbahan PVC sebagai pengalir aliran sudah tepat.

Bak Penampungan Air hujan : Bahan bak penampung air hujan yang digunakan yaitu plastik dan ferrosemen yang dilapisi plastik polyethylene. Bak penampung berbahan plastik yang berupa beberapa jerican HDPE (high density polyethylene) dengan kapasitas setiap jerican 30 liter, drum plastik HDPE (high density polyethylene) kapasitas 150 liter dan tangki air polyethylene dengan kapasitas 3100 liter. Berikut ini merupakan hasil observasi jenis bahan bak penampungan air hujan:

Tabel 1. Jenis Bahan Bak Penampungan Air Hujan

\begin{tabular}{|c|c|c|}
\hline No. & $\begin{array}{l}\text { Alamat } \\
(\mathrm{RT} / \mathrm{RW})\end{array}$ & Jenis Bahan Bak Penampung \\
\hline 01 & $19 / 05$ & Plastik (7 jerican @30 liter) \\
\hline 02 & $19 / 05$ & $\begin{array}{l}\text { Ferrosemen berlapis plastik } \\
(24.000 \text { liter })\end{array}$ \\
\hline 03 & $19 / 05$ & Plastik (tangki 3.100 liter) \\
\hline 04 & $19 / 05$ & Plastik (1 drum plastik 150 liter) \\
\hline 05 & $19 / 05$ & $\begin{array}{l}\begin{array}{l}\text { Ferrosemen berlapis plastik } \\
(20.000 \text { liter })\end{array} \\
\end{array}$ \\
\hline 06 & $18 / 05$ & Plastik (tangki 3.100 liter) \\
\hline 07 & $18 / 05$ & Plastik (tangki 3.100 liter) \\
\hline 08 & $18 / 05$ & Plastik (6 jerican @30 liter) \\
\hline 09 & $18 / 05$ & $\begin{array}{l}\text { Ferrosemen berlapis plastik } \\
(15.000 \text { liter })\end{array}$ \\
\hline 10 & $18 / 05$ & Plastik (7 jerican @30 liter) \\
\hline 11 & $17 / 05$ & $\begin{array}{lll}\text { Ferrosemen berlapis } & \text { plastik } \\
\text { (8.000 liter) } & & \\
\end{array}$ \\
\hline 12 & $17 / 05$ & Plastik (7 jerican @30 liter) \\
\hline 13 & $17 / 05$ & Plastik (9 jerican @30 liter) \\
\hline 14 & $17 / 05$ & $\begin{array}{l}\text { Ferrosemen berlapis plastik } \\
(20.000 \text { liter) }\end{array}$ \\
\hline 15 & $17 / 05$ & Plastik (6 jerican @30 liter) \\
\hline 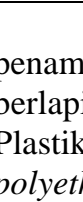 & $\begin{array}{l}\text { Ferrosemer } \\
\text { pung air } 1\end{array}$ & $\begin{array}{l}\text { berlapis plastik : Pengguna bak } \\
\text { ujan yang berjenis ferrosemer } \\
\text { jumlah } 5 \text { responden atau } 33,3 \% \\
\text { nakan sebagai pelapis berjeni }\end{array}$ \\
\hline
\end{tabular}


crystalline. Menurut UNEP (2001), penggunaan polyethylene sebagai bahan bak penampung merupakan pilihan yang tepat.

Jerican : Pengguna bak penampung air hujan yang berupa jerican ada 6 responden. Pengguna jerican menampung air hujan lebih dari satu kali dalam sehari tergantung dari jumlah hujan pada hari itu. Jerican yang digunakan berbahan dasar high density polyethylene (HDPE).

HDPE merupakan salah satu bahan plastik yang aman untuk digunakan karena kemampuan untuk mencegah reaksi kimia antara kemasan plastik berbahan HDPE dengan makanan/minuman yang dikemasnya. Sama seperti PET, HDPE juga direkomendasikan hanya untuk sekali pemakaian, karena pelepasan senyawa antimoni trioksida terus meningkat seiring waktu (Syamsul, 2010 h. 20). HDPE adalah polimer termoplastik linear yang dibuat dari monomer etilen dengan proses katalitik. HDPE dengan sedikit cabang menghasilkan struktur yang lebih rapat/terjejal dengan densitas yang lebih tinggi dan mempunyai ketahanan kimia yang lebih tinggi daripada LDPE (Yatim et al, 2009 h.348).

Drum Plastik : Pengguna bak penampung air hujan yang berupa drum plastik ada 1 responden atau 6,7\%. Responden menggunakan 1 unit drum berbahan high density polyethylene (HDPE) berkapasitas 150 liter untuk menampung air hujan. Terdapat talang air PVC sebagai pengalir aliran.

Tangki Air : Pengguna bak penampung air hujan yang berupa tangki air ada 3 responden atau 20\%. Tangki air yang digunakan berbahan dasar polyethylene. Ada responden yang menggunakan talang air sebagai pengalir aliran, namun ada juga yang tidak menggunakan talang air.

Menurut UNEP (2001), bak penampung air hujan sebaiknya terbuat dari material inert, beton bertulang, fiberglass, polyethylene, dan stainless steel. Tangki ferrosemen yang terbuat dari mortar adalah yang paling umum digunakan. Dengan demikian, penggunaan jenis bahan bak penampungan air hujan di Dusun Bambangan sudah tepat. Namun, terdapat hal yang harus diwaspadai yaitu penggunaan bak berbahan plastik yang berpotensi terjadi migrasi senyawa kimia dari bak penampungan ke air yang ditampung.

Kondisi Bak Penampungan Air Hujan : Kondisi bak penampungan air hujan di Dusun Bambangan terbagi menjadi dua jenis yaitu bak penampungan yang kondisinya tertutup dan bak penampungan yang kondisinya terbuka. Bak penampungan dengan kondisi tertutup adalah bak ferrosemen berlapis plastik sedangkan bak penampungan dengan kondisi terbuka adalah bak yang terbuat dari plastik yaitu drum, jerican dan tangki air. Berikut ini merupakan hasil observasi kondisi bak penampungan air hujan di Dusun Bambangan:
Tabel 2. Kondisi Bak Penampungan Air Hujan

\begin{tabular}{ccc}
\hline No. & Alamat (RT/RW) & $\begin{array}{c}\text { Kondisi Bak } \\
\text { Penampung }\end{array}$ \\
\hline 01 & $19 / 05$ & Terbuka \\
\hline 02 & $19 / 05$ & Tertutup \\
\hline 03 & $19 / 05$ & Terbuka \\
\hline 04 & $19 / 05$ & Terbuka \\
\hline 05 & $19 / 05$ & Tertutup \\
\hline 06 & $18 / 05$ & Terbuka \\
\hline 07 & $18 / 05$ & Terbuka \\
\hline 08 & $18 / 05$ & Terbuka \\
\hline 09 & $18 / 05$ & Tertutup \\
\hline 10 & $18 / 05$ & Terbuka \\
\hline 11 & $17 / 05$ & Tertutup \\
\hline 12 & $17 / 05$ & Terbuka \\
\hline 13 & $17 / 05$ & Terbuka \\
\hline 14 & $17 / 05$ & Tertutup \\
\hline 15 & $17 / 05$ & Terbuka \\
\hline \multicolumn{3}{c}{$\begin{array}{c}\text { Menurut UNEP } \\
\text { terbuka } \text { tidak }\end{array}$} \\
yang direkomendasikan untuk
\end{tabular}
menyimpan air yang akan dimanfaatkan sebagai air minum. Sebuah tutup yang aman diperlukan untuk mencegah perkembangbiakan nyamuk, mencegah masuknya serangga dan hewan lainnya kedalam bak penampungan dan untuk menghindari masuknya sinar matahari kedalam bak untuk mencegah tumbuhnya alga. Kondisi bak penampungan yang terbuka di Dusun Bambangan menyebabkan terdapat partikel kotoran berupa debu dan dedaunan di dalam bak penampungan air hujan. Hal ini akan menyulitkan pemanfaatan penampungan air hujan karena pengguna harus mengendapkan airnya terlebih dahulu.

Unit Pengolah Air Hujan : Media penyaring yang digunakan berupa kain yang diletakkan di pangkal talang air. Air yang mengalir dari bidang penangkap akan disaring terlebih dahulu sebelum mengalir melalui talang. Tidak semua warga menggunakan media penyaring. Berikut ini merupakan hasil observasi unit pengolah air hujan di Dusun Bambangan :

Tabel 3. Unit Pengolah Air Hujan

\begin{tabular}{ccc}
\hline No. & $\begin{array}{c}\text { Alamat } \\
\text { (RT/RW) }\end{array}$ & Unit Pengolah Air Hujan \\
\hline 01 & $19 / 05$ & Tidak ada \\
\hline 02 & $19 / 05$ & Ada \\
\hline 03 & $19 / 05$ & Tidak ada \\
\hline 04 & $19 / 05$ & Tidak ada \\
\hline 05 & $19 / 05$ & ada \\
\hline 06 & $18 / 05$ & Tidak ada \\
\hline 07 & $18 / 05$ & Tidak ada \\
\hline 08 & $18 / 05$ & Tidak ada \\
\hline 09 & $18 / 05$ & ada \\
\hline 10 & $18 / 05$ & Tidak ada \\
\hline 11 & $17 / 05$ & ada \\
\hline 12 & $17 / 05$ & Tidak ada \\
\hline 13 & $17 / 05$ & Tidak ada \\
\hline 14 & $17 / 05$ & ada \\
\hline 15 & $17 / 05$ & Tidak ada \\
\hline
\end{tabular}


Menurut Peraturan Menteri Pekerjaan Umum dan Perumahan Rakyat Nomor 27/PRT/2016 tentang Penyelenggaraan Sistem Air Minum, unit pengolahan air hujan yang biasa digunakan yaitu berupa saringan yang berfungsi menyaring air hujan dari kotoran. Media penyaring dapat berupa pasir dengan kerikil/pecahan bata/marmer sebagai penyangga. Media penyaring ini dapat diletakkan di atas bak penampung dan/atau sebelum kran.

Penggunaan saringan kain membuat air dalam bak penampungan air hujan jernih, bersih dan bebas dari berbagai macam partikel kotoran. Sedangkan responden yang tidak menggunakan saringan, dalam bak penampungan air hujan terdapat kotoran berupa daun dan partikel kotoran yang berasal dari atap rumah. Air dari bak langsung digunakan untuk keperluan sehari-hari dengan cara dituang ke dalam bak dan penampungan air yang ada di dalam rumah. Responden yang tidak menggunakan saringan adalah responden dengan bak penampung berjenis plastik seperti drum, jerican dan tangki air.

II. Kualitas Air di Penampungan Air Hujan : Menurut UNEP dalam Yulistyorini (2011, h.110), air hujan hampir tidak mengandung kontaminan, oleh karena itu air tersebut sangat bersih dan bebas kandungan mikroorganisme. Namun, ketika air hujan tersebut kontak dengan permukaan tangkapan air hujan, tempat pengaliran air hujan dan tangki penampung air hujan, maka air tersebut akan membawa kontaminan baik fisik, kimia maupun mikrobiologi. Menurut Horn dan Helmreich (2009) dalam Yulistyorini (2011, h.111), di daerah pinggiran kota atau di pedesaan, umumnya air hujan yang ditampung sangat bersih. Sampel air hujan diambil dari penampungan air hujan yang berbahan plastik sebanyak 1 sampel dan dari penampungan air hujan yang berbahan ferrosemen berlapis plastik sebanyak 1 sampel. Kualitas air yang diukur adalah suhu, pH, kekeruhan dan Fluorida.

Suhu : Suhu atau temperatur air akan mempengaruhi kesukaan konsumen terhadap air tersebut. Penyimpangan terhadap suhu air dapat mengakibatkan meningkatnya daya toksisitas bahan kimia dan meningkatkan pertumbuhan mikroba di dalam air (Sanropie et al, 1984 h.56). Berikut ini merupakan hasil pengukuran suhu air penampungan air hujan :

Tabel 4. Hasil Pengukuran Suhu Air PAH

\begin{tabular}{clccc}
\hline No. & Bahan Bak & $\begin{array}{c}\text { Kondisi } \\
\text { Bak }\end{array}$ & $\begin{array}{c}\text { Unit } \\
\text { Pengolah } \\
\text { Air } \\
\text { Hujan }\end{array}$ & $\begin{array}{c}\text { Suhu } \\
\left({ }^{\circ} \mathrm{C}\right)\end{array}$ \\
\hline 01 & $\begin{array}{l}\text { Plastik } \\
\text { (jerican) }\end{array}$ & Terbuka & $\begin{array}{c}\text { Tidak } \\
\text { ada }\end{array}$ & 20 \\
02 & $\begin{array}{l}\text { Ferroseme } \\
\text { n berlapis } \\
\text { plastik }\end{array}$ & Tertutup & Ada & 21 \\
\hline
\end{tabular}

Suhu sampel pertama yaitu $20^{\circ} \mathrm{C}$. Sampel pertama merupakan air dari penampungan air hujan milik responden nomor 01 . Bak penampungan terbuat dari bahan jerican HDPE, kondisi bak terbuka dan tidak terdapat unit pengolah air hujan.

Suhu sampel kedua adalah $21^{\circ} \mathrm{C}$. Sampel kedua merupakan air dari penampungan air hujan milik responden nomor 02 . Bak penampungan terbuat dari bahan ferrosemen berlapis plastik polyethylene, kondisi bak tertutup dan terdapat unit pengolah air hujan berupa saringan kain. Berdasarkan Peraturan Menteri Kesehatan RI No.32 tahun 2017, suhu sampel air responden 01 dan 02 masih memenuhi syarat.

pH : Derajat keasaman atau $\mathrm{pH}$ merupakan salah satu faktor yang sangat penting. $\mathrm{pH}$ dapat menyebabkan perubahan kimiawi di dalam air. Apabila pH lebih kecil dari 6,5 atau lebih besar dari 9,2, dapat menyebabkan korosifitas pada pipa-pipa air yang dibuat dari logam dan dapat mengakibatkan beberapa senyawa kimia berubah menjadi racun yang dapat mengganggu kesehatan manusia (Sanropie et al, 1984 h.57). Menurut Qasim (2002, h.22), pH air hujan pada umumnya adalah 7,0. Berikut ini merupakan hasil pengukuran $\mathrm{pH}$ air penampungan air hujan :

Tabel 5. Hasil Pengukuran pH Air PAH

\begin{tabular}{ccccc}
\hline No. & Bahan Bak & $\begin{array}{c}\text { Kondisi } \\
\text { Bak }\end{array}$ & $\begin{array}{c}\text { Unit } \\
\text { Pengolah } \\
\text { Air Hujan }\end{array}$ & $\mathrm{pH}$ \\
\hline 01 & $\begin{array}{l}\text { Plastik } \\
\text { (jerican) }\end{array}$ & Terbuka & Tidak ada & 8,1 \\
02 & $\begin{array}{l}\text { Ferrosemen } \\
\text { berlapis } \\
\text { plastik }\end{array}$ & Tertutup & Ada & 8,4 \\
\hline
\end{tabular}

pH sampel pertama yaitu 8,1. Sampel pertama merupakan air dari penampungan air hujan milik responden nomor 01. Bak penampungan terbuat dari bahan jerican HDPE, kondisi bak terbuka dan tidak terdapat unit pengolah air hujan. $\mathrm{pH}$ sampel kedua adalah 8,4. Sampel kedua merupakan air dari penampungan air hujan milik responden nomor 02 . Bak penampungan terbuat dari bahan ferrosemen berlapis plastik polyethylene, kondisi bak tertutup dan terdapat unit pengolah air hujan berupa saringan kain. Berdasarkan Permenkes No. 32 Tahun 2017, pH sampel air responden 01 dan 02 memenuhi syarat.

Kekeruhan : Air dikatakan keruh, mengandung begitu banyak partikel bahan yang tersuspensi sehingga memberikan warna yang berlumpur atau kotor. Bahan-bahan yang menyebabkan kekeruhan ini meliputi : tanah liat, lumpur, bahan organik yang tersebar secara baik dan partikel-partikel yang tersuspensi lainnya (Syamsul, 2010 h.31). Sanropie et al (1984, h. 57) menyatakan bahwa penyimpangan terhadap standar kualitas dalam hal kekeruhan melebihi batas yang telah ditetapkan akan menyebabkan berkurangnya efektivitas desinfeksi air. Berikut ini merupakan hasil pengukuran kekeruhan air penampungan air hujan : 
Tabel 6. Hasil Pengukuran Kekeruhan Air PAH

\begin{tabular}{ccccc}
\hline No. & $\begin{array}{c}\text { Bahan } \\
\text { Bak }\end{array}$ & $\begin{array}{c}\text { Kondisi } \\
\text { Bak }\end{array}$ & $\begin{array}{c}\text { Unit } \\
\text { Pengolah } \\
\text { Air } \\
\text { Hujan }\end{array}$ & $\begin{array}{c}\text { Kekeruh } \\
\text { an } \\
\text { (NTU) }\end{array}$ \\
\hline 01 & $\begin{array}{l}\text { Plastik } \\
\text { (jerican) }\end{array}$ & Terbuka & $\begin{array}{c}\text { Tidak } \\
\text { ada }\end{array}$ & $<5$ \\
02 & $\begin{array}{l}\text { Ferrosem } \\
\text { en } \\
\text { berlapis } \\
\text { plastik }\end{array}$ & Tertutup & Ada & $<5$ \\
\hline & & & \\
\hline
\end{tabular}
hujan dilakukan kepada dua responden yaitu responden nomor 01 dan responden 02. Kedua sampel memiliki kekeruhan <5 NTU. Berdasarkan Permenkes No. 32 Tahun 2017, kekeruhan sampel responden 01 dan 02 memenuhi syarat kekeruhan air bersih yang ditetapkan yaitu 25 NTU.

Fluorida : Fluorida adalah zat yang unik karena adanya konsentrasi tertinggi dan terendah dalam air minum yang diketahui dapat mengakibatkan efek yang mengganggu maupun yang bermanfaat bagi manusia. Konsentrasi rendah $(0,5-1,0 \mathrm{mg} /$ liter $)$ memberi perlindungan terhadap karies gigi, khususnya pada anak-anak. Konsentrasi minimum fluorida dalam air minum yang harus dicapai adalah $0,5 \mathrm{mg} /$ liter. Untuk proses fluoridasi air minum, nilai yang ditetapkan adalah 0,5 - 1,0 mg/liter (WHO, 2004). Pemeriksaan fluorida dilakukan di Laboratorium Kesehatan Masyarakat Kabupaten Banyumas dengan metode spektrofotometri. Sampel air hujan yang diperiksa sebanyak 2 sampel yaitu sampel air dari responden 01 dan sampel air dari responden 02. Berikut ini merupakan hasil pemeriksaan fluorida air penampungan air hujan :

Tabel 7. Hasil Pemeriksaan Fluorida Air PAH

\begin{tabular}{ccccc}
\hline No. & $\begin{array}{c}\text { Bahan } \\
\text { Bak }\end{array}$ & $\begin{array}{c}\text { Kondisi } \\
\text { Bak }\end{array}$ & $\begin{array}{c}\text { Unit } \\
\text { Pengola } \\
\text { h Air } \\
\text { Hujan }\end{array}$ & $\begin{array}{c}\text { Fluorida } \\
(\mathrm{Mg} / \mathrm{L})\end{array}$ \\
\hline 01 & $\begin{array}{l}\text { Plastik } \\
\text { (jerican) }\end{array}$ & Terbuka & $\begin{array}{c}\text { Tidak } \\
\text { ada }\end{array}$ & 0,0004 \\
02 & $\begin{array}{l}\text { Ferrosem } \\
\text { en } \\
\text { berlapis } \\
\text { plastik }\end{array}$ & Tertutup & Ada & 0,0002 \\
\hline
\end{tabular}

Responden 01 adalah pengguna bak penampungan jerican HDPE tanpa talang dan saringan sedangkan responden 02 adalah pengguna bak penampungan ferrosemen berlapis plastik dengan talang dan saringan. Kandungan fluorida pada sampel air responden 01 adalah $0,0004 \mathrm{mg} / \mathrm{liter}$ dan kandungan fluorida pada sampel air responden 02 adalah $0,0002 \mathrm{mg} / \mathrm{liter}$.

Qasim (2002, h.22) menyatakan bahwa air hujan tidak mengandung mineral fluorida. Namun, sampel air hujan di PAH Dusun Bambangan mengandung fluorida sebesar 0,0004 mg/liter untuk responden 01 dan $0,0002 \mathrm{mg} /$ liter untuk responden 02. Menurut Sanropie (1984, h. 55), penyimpangan kualitas air dapat diakibatkan salah satunya oleh sistem pengolahan air yang digunakan. Kandungan fluorida pada sampel responden 01 dan 02 dapat berasal dari migrasi zat dari komponen penampungan air hujan. Komponen tersebut adalah bidang penangkap (atap), talang air, saringan dan bak penampung air hujan.

Menurut Klima-og Forurensningsdirektoratet (2013, h.104), salah satu bahan yang digunakan untuk pembuatan berbagai jenis plastik adalah perfluorooctanoic acid (PFOA) dan senyawa sejenis. PFOA digunakan dalam jumlah yang sangat sedikit sebagai dispersing agent. PFOA tidak terikat secara kimiawi, zat ini akan bermigrasi. Percobaan mengenai migrasi PFOA dilakukan dengan wajan penggorengan Teflon® (Du Pont PTFE) yang dipanaskan menunjukkan adanya pelepasan asam perfluorocarboxylic pada suhu $360^{\circ} \mathrm{C}$ (Sebuah wajan yang berlapis PTFE dapat mencapai $400^{\circ} \mathrm{C}$ ). Dengan demikian, diduga bahwa kandungan fluorida di sampel responden berasal dari migrasi perfluorooctanoic acid (PFOA) dan senyawa sejenis dari bahan bak penampung. Oleh karena itu, diperlukan penelitian lebih lanjut terkait migrasi perfluorooctanoic acid (PFOA) dan senyawa sejenis dari bak penampungan air hujan yang berbahan plastik ke dalam air.

Kandungan fluorida kedua sampel adalah 0,0004 mg/liter untuk responden 01 dan 0,0002 $\mathrm{mg} / \mathrm{liter}$ untuk responden 02. Nilai tersebut sangat kecil dibandingkan dengan batas minimal yang ditetapkan oleh WHO yaitu 0,5 - 1,0 mg/liter. Kandungan fluorida yang sangat sedikit dapat meningkatkan prevalensi karies gigi. Angela (2005, h.132) menyatakan bahwa pada anak yang berisiko karies tinggi dilaporkan bahwa penggunaan fluor ini hampir tidak ada. Untuk mengatasi permasalahan ini, alternatif yang dapat dilakukan adalah melakukan fluoridasi air dan mengonsumsi fluorida dari sumber lain seperti makanan dan pasta gigi. Konsumsi fluorida makanan seperti sayuran, susu, telur, daging dan penggunaan pasta gigi berfluorida lebih direkomendasikan karena lebih terjangkau dan mudah untuk dilakukan.

\section{Penutup}

Kesimpulan : Penduduk Dusun Bambangan menggunakan bahan bidang penangkap air hujan berjenis seng galvalum. Unit pengolahan air hujan yang digunakan berupa saringan kain. Bahan bak penampungan air hujan yang digunakan terdiri dari ferrosemen berlapis plastik polyethylene, jerican high density polyethylene, drum high density polyethylene dan tangki air polyethylene. Kandungan fluorida pada air di penampungan air hujan adalah $0,0002 \mathrm{mg} / \mathrm{liter}$ $0,0004 \mathrm{mg} /$ liter. Suhu air di penampungan air hujan adalah $20^{\circ} \mathrm{C}-21^{\circ} \mathrm{C}$. Kekeruhan air di penampungan air hujan adalah $<5 \mathrm{NTU}$. $\mathrm{pH}$ air di penampungan air hujan adalah $8,1-8,4$.

Saran : Sebaiknya sistem penampungan air hujan dilengkapi dengan komponen dan proses 
pengolahan air hujan sesuai Peraturan Menteri Pekerjaan Umum dan Perumahan Rakyat Nomor 27/PRT/2016 dan perlu dilakukan proses fluoridasi air PAH. Untuk mencukupi kebutuhan fluorida, sebaiknya penduduk Dusun Bambangan mengonsumsi makanan yang mengandung fluorida dan pasta gigi berfluorida. Diperlukan penelitian lebih lanjut tentang migrasi senyawa perfluorooctanoic acid (PFOA) dan senyawa sejenis dari bak penampung air hujan.

\section{Daftar Pustaka}

Achmad, Rukaesih, 2004, Kimia Lingkungan. Yogyakarta: Andi Offset

Anie, Yulistyorini, 2011, Pemanenan Air Hujan Sebagai Alternatif Pengelolaan Sumber Daya Air Di Perkotaan, Univeritas Negeri Malang: Majalah Teknologi Dan Kejuruan, Vol. 34, No. 1, (Februari 2011:105-114)

Dégremont, Gilbert. 1991. Water Treatment Handbook. France: DÉGREMONT

Depkes RI, 1990, Peraturan Menteri Kesehatan Republik Indonesia Nomor 32 Tahun 2017, tentang Standar Baku Mutu Kesehatan Lingkungan Dan Persyaratan Kesehatan Air Untuk Keperluan Higiene Sanitasi, Kolam Renang, Solus Per Aqua, Dan Pemandian Umum. Jakarta: Depkes RI

Djasio, Sanropie dkk, 1984, pedoman bidang studi Penyediaan Air Bersih sekolah pembantu penilik higiene SPPH, Proyek Pengembangan Pendidikan Tenaga Sanitasi Pusat Pusat Pendidikan dan Latihan Pegawai Departemen Kesehatan RI

Foth, D. Henry. 1998. Dasar-Dasar Ilmu Tanah, Yogyakarta: Gadjah Mada University Press.

G. Alerts dan Sri Sumestri Santika, 1987,Metode Penelitian Air, Surabaya: Usaha Nasional

Hadisusanto, Nugroho. 2011. Aplikasi Hidrologi. Yogyakarta: Jogja Mediautama

http://www.ampl.or.id/digilib/read/isu-isu-strategispermasalahan/4998, "Isu Strategis dan Permasalahan"diakses pada desember 2017

http://www.kelair.bppt.go.id/sitpapdg/Patek/Spah/spah .html, "Sistem Pemanfaatan Air Hujan (SPAH) dan Pengolahan Air Siap Minum (ARSINUM)",onlinediakses pada Desember 2017 http://www.perpamsi.or.id/berita/view/2018/03/22/468 /selamat-hari-air-dunia-2018, "Selamat Hari Air Dunia 2018” diakses pada Juni 2018

http://www.sanitasi.or.id/?p=709, "Sanitasi dan Sustainable Development Goals (SDG's)" diakses pada Juni 2018

Jennifer, Bills Sumiok, dkk, 2015, Gambaran Kadar Fluor Air Sumur Dengan Karies Gigi Anak di Desa Boyongpante Dua 2015, Universitas Sam Ratulangi: Majalah Ilmiah Farmasi - UNSRAT Vol. 4 No. 4 November 2015

Klima- og Forurensningsdirektoratet, 2013, Hazardous Substances In Plastic Materials, Denmark: Danish Institute of Technology

Kodoatie, J. Robert dan Roestam Sjarief, 2008, Pengelolaan Sumber Daya Air Terpadu. Yogyakarta: ANDI offset

Laboratorium Kesehatan Masyarakat Banyumas, Panduan Pelaksanaan Pemeriksaan Sampel Air Laboratorium Kesehatan Masyarakat Kabupaten Banyumas.

Muharti, Syamsul, 2010, "Studi Tentang Kualitas Fisik Air Minum dalam Kemasan (Amdk) Sebelum Dan Sesudah Terpapar Oleh Cahaya Matahari Di Kota Makassar Tahun 2010". Skripsi. Universitas Islam Negeri Alauddin Makassar: Jurusan Kesehatan Masyarakat

Netherlands Water Partnership. 2007. Smart Water HarvestingSolutions. Netherland: NWP

Peraturan Menteri Pekerjaan Umum Republik Indonesia nomor 11/PRT/M/2014 tentang Pengelolaan Air Hujan pada Bangunan Gedung dan Persilnya

Peraturan Menteri Pekerjaan Umum Dan Perumahan Rakyat Nomor 27/PRT/M/2016 Tentang Penyelenggaraan Sistem Penyediaan Air Minum

Qasim, Syed R, dkk. 2002. Water Works Engineering: Planning Design and Operation. New Delhi: Prentice-Hall of India Private Limited

Qonitati, 2013, "Studi Pengelolaan Air Bersih pada Pelaksanaan Program Penyediaan Air Minum dan Sanitasi Berbasis Masyarakat (Pamsimas) di Desa Sikasur, Kecamatan Belik, Kabupaten Pemalang Tahun 2013" KTI, Politeknik Kesehatan Kementerian Kesehatan Semarang: Jurusan Kesehatan Lingkungan Purwokerto 
Standar Nasional Indonesia SNI 6989.57:2008, Air dan air limbah - Bagian 57: Metoda pengambilan contoh air permukaan, Jakarta: Badan Standarisasi Nasional

Sutrisno, Totok, dkk. 2010. Teknologi Penyediaan Air Bersih. Jakarta: Rineka Cipta

Thomas, T.H. dan Martinson, D.B. 2007, Roofwater Harvesting: A Handbook of Practicioners. Delft, The Netherlands: IRC International Water and Sanitation Centre. (Technical Paper Series; no. 49). 160 p.

UNEP, 2001, Rainwater Harvesting and Utilisation: An Environmentally Sound Approach for Sustainable Urban Water Management.

Untari, Tanti dan Joni Kusnadi, 2015, Pemanfaatan Air Hujan Sebagai Air Layak Konsumsi Di Kota Malang Dengan Metode Modifikasi Filtrasi Sederhana, Universitas Brawijaya: Jurnal Pangan dan Agroindustri Vol. 3 No 4 p.1492-1502.

World Health Organization. 2014. Pedoman Mutu Air Minum Edisi 3. Jakarta: EGC

Yatim, Lailun, dkk, 2009,Synthesis And Characterization Of HDPE Plastic Film For Herbicide Container Using Fly Ash Class F As Filler, Institut Teknologi Sepuluh November: Indo. J. Chem, 2009, 9 (3), 348 - 354, 